\title{
SKRINING BAKTERI TERMOFILIK POTENSIAL AMILOLITIK DARI SUMBER AIR PANAS WAY BELERANG KALIANDA LAMPUNG SELATAN
}

\section{SCREENING OF AMYLOLITIC POTENTIAL THERMOPHILIC BACTERIA FROM WAY BELERANG HOT SPRING KALIANDA LAMPUNG SELATAN}

\author{
Sefi Desfeni Mawati1,*, Esti Harpeni' ${ }^{2}$, Hilma Putri Fidyandini ${ }^{2}$ \\ ${ }^{1}$ Mahasiswa Program Studi Budidaya Perairan, Fakultas Pertanian, Universitas Lampung, Lampung, \\ Indonesia \\ ${ }^{2}$ Dosen Program Studi Budidaya Perairan, Fakultas Pertanian, Universitas Lampung, Lampung, Indonesia \\ *email penulis korespondensi: sefidesfeni05@gmail.com
}

\begin{abstract}
Abstrak
Bakteri termofilik telah diisolasi dari sumber air panas Way Belerang, Kalianda, Lampung Selatan merupakan penghasil enzim amilase. Penelitian ini bertujuan untuk melakukan skrining bakteri termofilik yang berpotensi menghasilkan enzim amilase dan protease termostabil. Prosedur penelitian yang dilakukan meliputi, pengambilan sampel, isolasi bakteri termofilik, isolasi bakteri termofilik penghasil enzim, rangkaian uji morfologi dan biokimia, serta identifikasi secara molekuler. Penelitian ini dilakukan menggunakan 2 perlakuan yaitu suhu inkubasi 37 dan $50 \stackrel{\circ}{\circ}$ dengan 3 kali ulangan. Hasil yang diperoleh menunjukan bahwa suhu optimum pertumbuhan isolat bakteri termofilik dan isolat bakteri temofilik penghasil enzim amilase adalah $50^{\circ} \mathrm{C}$. Isolat bakteri yang menghasilkan enzim amilase terbesar adalah isolat dengan nama A.WB.50.1. dengan besar diameter zona hambat 15,44 mm. Isolat A.WB.50.1 telah diidentifikasi dengan nama spesies Pseudomonas stutzeri.
\end{abstract}

Kata Kunci: Amilase, Bakteri termofilik, Enzim termostabil, Pseudomonas stutzeri

\begin{abstract}
Thermophilic bacteria that produced amylase and protease have been isolated from Way Belerang hot spring, Kalianda, South Lampung. This research aims to screen and identify thermophilic bacteria that have the potential to produce thermostable amylase and protease enzymes. The research procedures included sampling, isolation of enzyme-producing thermophilic bacteria, a series of phenotypic and biochemical tests, and molecular identification by 16s rRNA. This study used 2 treatments, namely incubation temperature 37 and $50 \stackrel{\circ}{\circ}$ with 3 repetitions. The results showed that the optimum temperature for growth of thermophilic bacterial isolates and thermophilic bacterial isolates producing amylase enzymes was $50^{\circ} \mathrm{C}$. The bacteria isolate that had the best amylolytic enzyme activity was Isolate A.WB.50.1 with a diameter of the inhibitory zone was $15.44 \mathrm{~mm}$. Isolate A.WB.50.1 has been identified by the species Pseudomonas stutzeri.
\end{abstract}

Keywords: Amylase, Thermophilic bacteria, Thermostable enzymes, Pseudomonas stutzeri

\section{PENDAHULUAN}

Sumber air panas dapat ditemukan di wilayah yang terdapat aktivitas vulkanik seperti adanya gunung berapi yang aktif. Provinsi Lampung merupakan salah satu yang termasuk dalam daratan pulau vulkanik Sumatera, dikarenakan terdapat beberapa gunung berapi aktif sehingga banyak ditemukan sumber air panas seperti sumber air panas Way Belerang, Kalianda, Lampung Selatan. Berdasarkan survei yang telah dilakukan pada beberapa sumber air panas tersebut mempunyai suhu berkisar antara 40ㅇ-65으. Menurut Prescott et al., (2008), bakteri termofilik merupakan mikroorganisme yang mampu hidup dalam kisaran suhu 45-65드. Bakteri temofilik mengandung protein tahan panas dan tahan terhadap denaturasi, sehingga dapat beradaptasi dalam suhu yang ekstrim, sehingga sumber air panas tersebut berpotensi menjadi habitat alami bakteri termofilik.

Bakteri termofilik mampu bertahan dan berkembang dalam kondisi suhu tinggi karena protein bakteri termofilik lebih stabil dan tahan 
panas dibandingkan dengan mesofil. Protein yang terdapat pada sel bakteri termofilik memiliki ikatan hidrofobik dan ikatan ionik yang sangat kuat. Komposisi membran sel pada bakteri termofilik tersusun oleh asam lemak jenuh sehingga dapat bersifat stabil pada suhu tinggi (Endah et al., 2012).

Enzim yang berasal dari mikroorganisme termofilik memiliki nilai komersial yang cukup tinggi di bidang industri dan bioteknologi karena memiliki termostabilitas yang tinggi, stabil terhadap zat-zat yang bersifat mendenatuasi enzim, serta stabil dalam lingkungan yang asam maupun alkalis. Kelebihan tersebut yang menjadikan enzim termostabil semakin berkembang penggunaannya dibidang industri dan bioteknologi (Sianturi, 2008).

Enzim amilase dapat memecah ikatanikatan pada amilum hingga terbentuk maltosa. Ada tiga macam enzim amilase, yaitu $\alpha$ amilase, $\beta$ amilase dan $\gamma$ amilase. $\alpha$ amilase terdapat dalam saliva (ludah) dan pankreas. Enzim ini memecah ikatan yang terdapat dalam amilum dan disebut endo amilase sebab enzim ini memecah bagian dalam atau bagian tengah molekul amilum. Enzim $\alpha$ amilase berperan dalam melakukan hidrolisis awal makanan terutama yang mengandung pati. $\beta$ amilase terutama terdapat pada tumbuhan dan dinamakan ekso-amilase sebab memecah dua unit glukosa yang terdapat pada ujung molekul amilum secara berurutan sehingga pada akhirnya terbentuk maltosa. $\gamma$ amilase telah diketahui terdapat dalam hati. Enzim ini dapat memecah ikatan 1-4 dan 1-6 pada glikogen dan menghasilkan glukosa (Poedjiadi dan Supriyanti, 2009).

\section{MATERI DAN METODE}

\section{Sterilisasi}

Sterilisasi dilakukan pada alat-alat dan media yang akan digunakan dalam penelitian ini. Alatalat dan media disterilisasi menggunakan autoklaf dengan suhu $121^{\circ} \mathrm{C}$ dan tekanan $15 \mathrm{psi}$ atau sekitar 2 atm selama 1 jam. Alat dan media yang disterilisasi merupakan alat yang tahan panas sehingga tidak mengalami kerusakan pada saat proses sterilisasi.

\section{Pengambilan Sampel}

Pengambilan sampel dilakukan di sumber air panas Way Belerang, Kecamatan Kalianda, Kabupaten Lampung Selatan. Sampel diambil mengunakan botol steril sebanyak $100 \mathrm{ml}$, kemudian dimasukan kedalam termos air panas dengan tujuan suhu sampel air panas tetap terjaga dan dimasukan ke dalam wadah sampel supaya terhindar dari kontaminasi.

\section{Pembuatan Media}

\section{a. Pembuatan Media NA (Nutrient Agar)}

Medium NA dibuat dengan menimbang NA sebanyak 28 g, kemudian di masukkan ke dalam gelas beaker dan ditambahkan aquades steril sampai volume $1000 \mathrm{~mL}$. Campuran dipanaskan menggunakan hotplate dan stirer sebagai pengaduk, setelah homogen medium dituangkan ke dalam erlenmeyer steril kemudian ditutup rapat dengan kapas dan alumunium foil. Medium disterilisasi di dalam autoklaf pada suhu $121^{\circ} \mathrm{C}$ selama 60 menit.

\section{b. Pembuatan Media Selektif}

Medium agar selektif amilolitik dibuat dengan cara menimbang yeast ekstrak sebanyak $2 \mathrm{~g}$, pepton $5 \mathrm{~g}, \mathrm{MgSO}_{4} .7 \mathrm{H}_{2} \mathrm{O} 0,5 \mathrm{~g}$, $\mathrm{NaCl} 0,5 \mathrm{~g}$, $\mathrm{CaCl}_{2} 2 \mathrm{H}_{2} \mathrm{O} 0,15 \mathrm{~g}$, pati $10 \mathrm{~g}$, dan agar $20 \mathrm{~g}$, kemudian bahan-bahan tersebut dimasukkan ke dalam gelas beaker dan ditambahkan aquades steril sampai volume $1000 \mathrm{~mL}$. Campuran dipanaskan sampai mendidih, setelah itu medium dituangkan ke dalam erlenmeyer steril kemudian ditutup rapat dengan kapas dan alumunium foil. Medium disterilisasi di dalam autoklaf pada suhu $121^{\circ} \mathrm{C}$ dan tekanan $15 \mathrm{psi}$ atau sekitar 2 atm selama 15 menit (Ginting, 2009).

\section{Isolasi dan Seleksi Isolat Bakteri Termofilik}

Sampel berasal dari sumber air panas diambil, sebanyak $200 \mu \mathrm{L}$ sampel air dimasukkan ke dalam erlenmeyer, kemudian di shaker selama 20-24 jam setelah itu sampel dituangkan ke dalam media padat Nutrient Agar (NA) dan diratakan menggunakan batang pengaduk (spreader). Kemudian sampel tersebut diinkubasi pada suhu 37 dan $50^{\circ} \mathrm{C}$ selama 48-72 jam. Isolat yang tumbuh dengan baik kemudian dimurnikan dengan cara digores dan diinkubasi kembali dengan suhu 37 dan $50^{\circ} \mathrm{C}$.

\section{Pemurnian Isolat Bakteri Termofilik}

Pemurnian bakteri dilakukan dengan tujuan untuk mendapatan kultur murni dari bakteri termofilik dari sampel air panas yang telah diisolasi. Pemurnian bakteri dilakukan dengan mengambil satu ose dari masing-masing koloni bakteri yang tumbuh berbeda pada medium NA sebelumnya dan diinokulasikan dengan ose ke dalam cawan petri lain yang mengandung medium NA, selanjutnya diinkubasi pada suhu 37 dan $50^{\circ} \mathrm{C}$.

\section{Seleksi Isolat Penghasil Enzim Amilase}

Isolat bakteri diinokulasi pada medium pati $1 \%$ dan diinkubasi selama 24 jam pada suhu 37 dan $50^{\circ} \mathrm{C}$. Isolat yang tumbuh kemudian ditetesi dengan larutan iodin untuk menyeleksi bakteri 
yang menghasilkan amilase. Isolat yang menghasilkan amilase ditunjukkan dengan adanya zona bening di sekitar koloni bakteri. Zona bening yang terbentuk pada sekitar bakteri diukur diameternya dengan menggunakan jangka sorong.

\section{Identifikasi Isolat Terpilih}

Identifikasi isolat bakteri dilakukan dengan menggunakan rangkaian uji biokimiawi dan uji morfologi, yaitu uji pewarnaan Gram, uji motilitas, uji katalase, dan uji oksidative fermentative $(\mathrm{O} / \mathrm{F})$. Identifikasi isolat bakteri ini beracuan pada Cowan dan Steels "Manual for the Identification of Medical Bacteria" (1974), prosedur kerja dari identifikasi isolat bakteri terpilih adalah sebagai berikut.

\section{a. Uji Pewarnaan Gram dan Identifikasi Fenotipik}

Teknik pewarnaan gram dilakukan untuk mengamati morfologi koloni. Pertama dibuat ulasan bakteri pada preparat kemudian difiksasi. Kemudian diteteskan larutan A (kristal violet) sebanyak 2-3 tetes, diamkan selama 60 detik. Preparat kemudian dicuci dengan menggunakan air mengalir dan dikeringkan. Kemudian diteteskan larutan B (lugol) sebanyak 2-3 tetes di atas preparat dan didiamkan selama 60 detik, selanjutnya dicuci dengan air mengalir dan dikeringkan. Setelah itu peparat ditetesi 2-3 tetes larutan alkohol-aseton, dibiarkan selama 60 detik dan dicuci kembali kemudian dikeringkan. Kemudian preparat ditetesi dengan larutan safranin sebanyak 2-3 tetes, didiamkan selama 60 detik selanjutnya dicuci dan dikeringkan.

Setelah dilakukan uji pewarnaan Gram preparat diamati di bawah mikroskop, untuk dilakukan identifikasi morfologi. Identifikasi morfologi dari bakteri, yaitu meliputi bentuk koloni, bentuk tepi elevasi, pertumbuhan pada media miring.

\section{b. Uji Motilitas}

Uji motilitas dilakukan untuk mengetahui kemampuan suatu bakteri untuk bergerak (Cowan dan Steel, 1974). Isolat diambil sebanyak 1 ose kemudian diinokulasi pada media SIM tegak dengan cara ditusuk, kemudian diinkubasi pada suhu 37 dan $50^{\circ} \mathrm{C}$ selama 48 jam. Apabila terdapat tanda rambatan-rambatan pada sekitar tusukan jarum ose dalam media maka hasilnya positif (motil). Apabila tidak ada tanda rambatanrambatan maka hasilnya negatif (non motil).

\section{c. Uji Katalase}

Uji katalase dilakukan untuk mengetahui kemampuan suatu bakteri dalam menghasilkan enzim katalase. Kemampuan menghasilkan enzim diketahui dengan adanya reaksi memecah hidrogen peroksida yang terbetuk dari hasil respirasi aerob yang bersifat toksik, menjadi hidrogen oksida $\left(\mathrm{H}_{2} \mathrm{O}\right)$ dan oksigen $\left(\mathrm{O}_{2}\right)$. Sebanyak 1 ose isolat diambil kemudian dicelupkan kedalam tabung reaksi berisi reagen $\mathrm{H}_{2} \mathrm{O}_{2}$. Hasil positif menunjukan terbentuknya gelembung gas pada ose, dan negatif jika tidak terbentuk gelembung gas.

\section{d. Uji Oksidative Fermentative (0/F)}

Uji oksidative fermentative adalah untuk mengetahui sifat oksidasi dan fermentasi suatu bakteri terhadap glukosa. Uji ini dilakukan untuk mengetahui kemampuan mikroorganisme untuk menggunakan karbohidrat dengan cara fermentasi atau oksidasi (Cowan dan Steels, 1974). Medium O/F disediakan dalam dua tabung reaksi selanjutnya dilakukan inokulasi bakteri ke medium. Pada salah satu tabung reaksi berisi medium yang telah diinokulasikan bakteri ditambahkan paraffin cair steril setebal $1 \mathrm{~cm}$. Inkubasi dilakukan pada suhu 37으 $\mathrm{C}$ selama $18-24$ jam. Pengamatan dilakukan dengan melihat perubahan warna yang terjadi dalam medium. Bakteri bersifat fermentatif jika kedua medium yang diinokulasi berubah warna menjadi kuning. Bakteri bersifat oksidatif jika tabung terbuka berwarna kuning, sedangkan yang ditutup paraffin warnanya tetap.

\section{Identifikasi Bakteri Secara Molekuler}

Identifikasi molekuler bakteri pada penelitian ini dilakukan dengan mengirimkan sampel isolat terpilih penghasil enzim amilase yang telah dimurnikan ke PT. INDOLAB UTAMA, Cengkareng, Jakarta Barat. Proses identifikasi bakteri termofilik yang dilakukan yaitu menggunakan metode sekuensing dengan membandingkan database nukleotida menggunakan program Basic Local Aligment Search Tool (BLAST) melalui situs www.ncbi.nlm.nih.gov/BLAST/. Hasil yang ditunjukan dari identifikasi bakteri secara molekuler ini adalah nama spesies bakteri dan tingkat kesamaan urutan nukleotida dari rRNA isolat dengan urutan nukleotida dari spesies bakteri yang sesuai dalam database Gene Bank.

\section{HASIL}

\section{Kualitas Air Sumber Air Panas Way Belerang}

Berdasarkan hasil pengamatan terhadap kualitas air dari sumber air panas Way Belerang Kalianda, Lampung Selatan didapatkan suhu yaitu $47^{\circ} \mathrm{C}$. Sumber air panas ini memiliki $\mathrm{pH}$ asam yaitu 5,0 dan merupakan sumber air tawar karena memiliki salinitas 0 . 


\section{Isolasi Bakteri Termofilik}

Penelitian ini dilaksanakan dengan 2 perlakuan suhu dalam proses inkubasi, yaitu menggunakan suhu 37 dan $50^{\circ} \mathrm{C}$. Jumlah isolat yang didapatkan pada suhu inkubasi $50^{\circ} \mathrm{C}$ lebih banyak dibandingkan pada suhu inkubasi $37^{\circ} \mathrm{C}$. Isolat paling banyak terdapat pada sampel WB.50.2 (Tabel 1).

Tabel 1. Jumlah isolat bakteri

\begin{tabular}{ccc}
\hline No & Sampel & Jumlah Isolat \\
\hline 1. & WB.37.1 & 2 \\
2. & WB.37.2 & 7 \\
3. & WB.37.3 & 3 \\
4. & WB.50.1 & 7 \\
5. & WB.50.2 & 12 \\
6. & WB.50.3 & 8 \\
\hline
\end{tabular}

\section{Seleksi Isolat Bakteri Penghasil Enzim Amilase}

Hasil dari isolasi bakteri termofilik yang telah dimurnikan kemudian diisolasi ke dalam media selektif amilase. Setelah diinkubasi menggunakan suhu 37 dan $50^{\circ} \mathrm{C}$, diperoleh 4 isolat yang mampu mendegradasi amilum dalam media selektif pati tersebut (Tabel 2). Hal ini ditunjukan dengan adanya zona bening di sekitar koloni bakteri setelah ditetesi larutan lugol. Isolat menghasilkan enzim amilase terbesar adalah isolat dengan kode A.WB.50.1. Isolat yang diinokulasi dalam medai selektif protease dengan suhu inkubasi 37 dan $50^{\circ} \mathrm{C}$ tidak mengalami pertumbuhan, sehingga tidak didapatkan hasil diameter zona bening pada koloni bakteri. Berikut merupakan data hasil pengukuran diameter zona bening pada isolat yang berpotensi menghasilkan enzim amilase.

Tabel 2. Isolasi bakteri penghasil enzim amilase

\begin{tabular}{|c|c|c|c|c|c|c|}
\hline No & Sampel Isolat & $\begin{array}{c}\text { Diameter Koloni } \\
(\mathrm{mm})\end{array}$ & $\begin{array}{c}\text { Diameter Zona } \\
\text { Bening }(\mathrm{mm})\end{array}$ & Warna koloni & $\begin{array}{l}\text { Bentuk } \\
\text { Koloni }\end{array}$ & Elevasi \\
\hline 1. & A.WB.37.1 & - & - & Putih susu & Sirkular & Datar \\
\hline 2. & A.WB. 37.2 & - & - & Putih susu & Sirkular & Datar \\
\hline 3. & A.WB.37.3 & - & - & Putih susu & Sirkular & Datar \\
\hline 4. & A.WB. 37.4 & - & - & Putih susu & Sirkular & Datar \\
\hline 5. & A.WB.50.1 & 8,14 & 15,44 & Putih susu & Sirkular & Datar \\
\hline 6. & A.WB.50.2 & 10,86 & 15,77 & Putih susu & Sirkular & Datar \\
\hline 7. & A.WB. 50.3 & 12,15 & 15,04 & Putih susu & Sirkular & Datar \\
\hline 8. & A.WB. 50.4 & 7,23 & 13,94 & Putih susu & Sirkular & Datar \\
\hline
\end{tabular}

Keterangan : A.WB. XX.X ( Amilase.Way Belerang.Perlakuan.Ulangan)

\section{Pengamatan Fenotipik Isolat Bakteri Termofilik Penghasil Enzim}

Isolat terpilih yang diketahui mampu menghasilkan enzim amilase, selanjutnya dilakukan identifikasi morfologi dan biokimiawi yang beracuan pada Cowan dan Steels "Manual for the Identification of Medical Bacteria" (1974).
Isolat yang digunakan adalah A.WB.50.1 dengan hasil pengamatan fenotipik yaitu memiliki bentuk koloni batang (Coccus). Isolat ini memiliki elevasi datar, bersifat motil, dan merupakan bakteri Gram negatif. Uji katalase pada isolat ini menunjukan hasil positif dan uji oksidatif/fermentatif (O/F) menujukan hasil oksidatif.

Tabel 3. Identifikasi Fenotipik dan Biokimia Isolat A.WB.50.1

\begin{tabular}{clcc}
\hline No & \multicolumn{1}{c}{ Karakteristik } & A.WB.50.1 & Pseudomonas \\
\hline 1. & Bentuk koloni & Batang & Batang \\
2. & Elevasi & Datar & Datar \\
3. & Gram & Negatif & Negatif \\
4. & Motilitas & Positif & Positif \\
5. & Katalase & Positif & Positif \\
6. & Oksidatif/Fermentatif & Oksidatif & Oksidatif \\
\hline
\end{tabular}

\section{Identifikasi Bakteri Secara Molekuler}

Identifikasi bakteri secara molekuler dalam penelitian ini dilakukan pada sampel isolat yang menghasilkan enzim amilase paling besar, yaitu isolat A.WB.50.1. Identifikasi molekuler dilakukan dengan cara isolat yang telah dimurnikan dan diberi nama kode sampel A.WB.S dikirim ke PT. Indolab Utama. Hasil analisis PCR- 
16S rRNA pada isolat yang diperoleh data berupa sekuen nukleotida dalam format FASTA seperti yang disajikan pada Gambar 1.

Format fasta merupakan format yang berisi huruf yang mewakili sekuen nukleotida atau sekuen protein. Pasangan basa dan asam amino diwakili dengan menggunakan huruf tunggal (Suyono, 2010). Format fasta memuat karakter sekuens yang dapat digunakan sebagai variasi program analisis serta untuk mendapatkan informasi tentang jenis mikroba yang memiliki tingkat kesamaan tertinggi dengan sampel mikroba. Format fasta tersebut diinput sebagai query dalam BLAST (Basic Local Alignment Search Tool) pada GeneBank NCBI (Ostell et al., 2001).

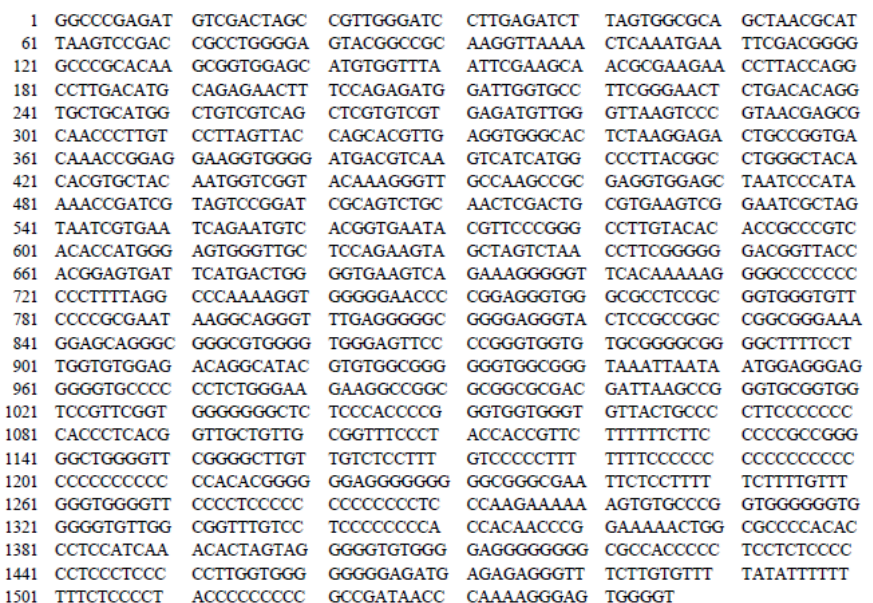

Gambar 1. Sekuens 16s rRNA isolat bakteri A.WB.50.1 dalam format fasta.

Hasil analisis BLAST menunjukkan nama spesies bakteri dan tingkat kesamaan pada urutan nukleotida dari rRNA isolat dengan urutan nukleotida dari spesies bakteri yang sesuai dalam database GeneBank. Berdasarkan Hasil analisis BLAST yang didapatkan dari sekuens RNA, menunjukan bahwa isolat A.WB.50.1 diperoleh hasil berupa nilai score 2691 dan Match Total 1466/1470 dengan persentase pct. 99\% dan merupakan bakteri Pseudomonas stutzeri (Gambar 2.)

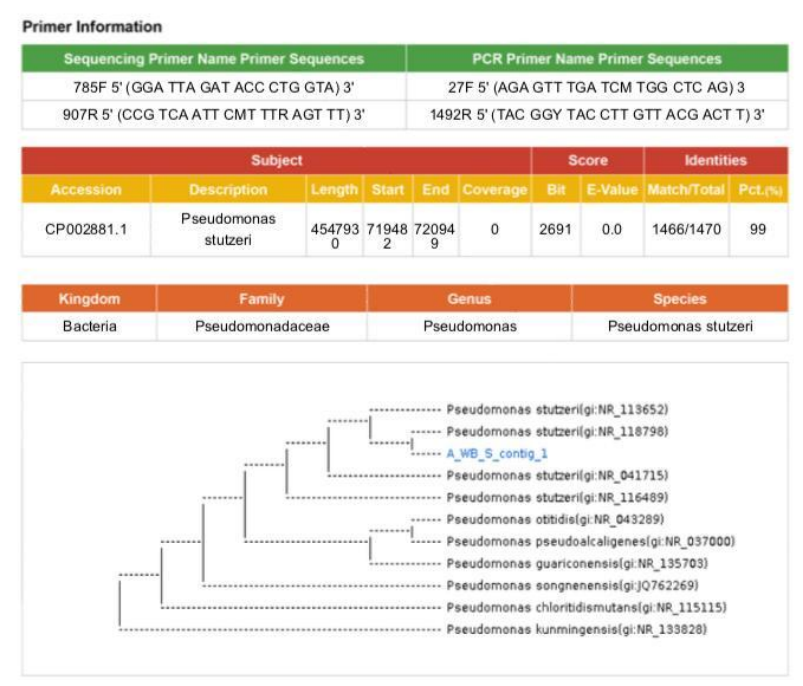

Gambar 2. Hasil analisis 16S rRNA dan pohon filogenetik.

\section{PEMBAHASAN}

Berdasarkan hasil penelitian, sampel air yang diambil dari sumber air panas Way Belerang, Kalianda, Lampung Selatan memiliki suhu 47-50ㅇ dan pH air 5,0. Menurut Prescott et al., (2008), bakteri termofilik merupakan bakteri yang bertahan hidup pada kisaran suhu 45-65으. Karina (2010), dalam penelitan serupa juga telah berhasil mengisolasi dan mengidentifikasi bakteri termofilik Pseudomonas sp. dan Vibrio sp. yang berasal dari sumber air panas Songgoriti dengan suhu $45^{\circ} \mathrm{C}$ dan $\mathrm{pH}$ 5,5. 
Berdasarkan penelitian yang telah dilakukan bahwa terdapat isolat yang tumbuh pada suhu 37 dan $50^{\circ} \mathrm{C}$. Masing-masing jumlah isolat yaitu, sebagai berikut : WB.37.1 : 2 isolat, WB.37.2 :7 isolat, WB.37.3: 3 isolat, WB.50.1: 7 isolat, WB.50.2: 12 isolat, dan WB.50.3: 8 isolat. Isolat-isolat yang tumbuh dilakukan seleksi isolat penghasil enzim amilase. Berdasarkan hasil pengamatan diketahui bahwa isolat bakteri pada suhu inkubasi $50^{\circ} \mathrm{C}$ menunjukan adanya aktifitas enzim pada media pati, yang artinya terdapat aktifitas enzim amilase oleh isolat bakteri tersebut. Hal ini ditunjukan dengan adanya zona bening di sekitar koloni setelah ditetesi larutan lugol. Isolat yang diinokulasi pada media selektif protease tidak terdapat aktifitas enzim. Isolat yang menunjukan zona bening paling besar adalah isolat dengan kode sampel A.WB.50.1 dengan diameter koloni 8,14 $\mathrm{mm}$ dan diameter zona bening 15,44 mm. Sampel isolat A.WB.50.1 adalah sampel yang kemudian dilakukan identifikasi secara molekuler.

Identifikasi sampel bakteri termofilik pada penelitian ini dilakukan di PT. Indolab Utama. Berdasarkan hasil yang didapatkan diketahui bahwa sampel A.WB.50.1 merupakan bakteri yang termasuk dalam genus Pseudomonas sp. dengan nama spesies Pseudomonas stutzeri. Bakteri Pseudomonas stutzeri merupakan bakteri Gram negatif, berbentuk batang, dan memiliki flagel kutub tunggal. Pseudomonas stutzeri dapat ditemukan dihampir semua jenis perairan dan tumbuh pada beberapan macam karbohidrat seperti pati, maltosa, dan pectin (Hardhianto et al., 2010).

Asnawi (2006) telah berhasil mengisolasi beberapa genus bakteri termofilik dari air panas Pacet, Jawa Timur, yaitu Bacillus $s p$, Thermus $s p$, Acetogenium sp, Pseudomonas sp. Rafiah (2016) dalam penelitian serupa telah berhasil mengidentifikasi bakteri termofilik yaitu genus Pseudomonas sp. dari sumber air panas Lejja, Kabupaten Soppeng. Bakteri termoflik yang berhasil diisolasi pada penelitian ini diketahui dapat menghidrolisis amilum pada media selektif pati, hal tersebut diartikan bahwa bakteri tersebut bersifat amilolitik. Berdasarkan penelitian yang telah dilakukan oleh Herlina (2010) menyatakan bahwa bakteri yang memiliki sifat amilolitik, proteolitik, dan lipolitik adalah bakteri Pseudomonas pseudomallei indeks 97,81\%, Pseudomonas stutzeri indeks 61,21\% dan Pseudomonas stutzeri indeks 97,81\%.

Bakteri termofilik yang berhasil diidentifikasi pada penelitian ini merupakan bakteri yang mampu menghasilkan enzim amilase. Hal ini sesuai dengan penelitian Syafriyani (2013) yang telah mengisolasi bakteri dari sumber air panas Sungai Medang yang mampu menghasilkan enzim amilase pada suhu
50 으. Enzim amilase yang dihasilkan oleh bakteri Pseodomonas stutzeri pada penelitian ini merupakan enzim termostabil. Hal ini dikarenakan zona bening yang terbentuk dalam media selektif pati merupakan sampel yang diinkubasi pada suhu $50^{\circ} \mathrm{C}$. Menurut Sutimiharja (2008) penggunaan enzim termostabil juga dapat memperkecil biaya produksi karena enzim ini dapat disimpan dalam waktu yang lebih lama dan tetap dapat bekerja optimal pada suhu yang tinggi. Salah satu enzim yang dihasilkan oleh bakteri termofilik adalah enzim amilase (Ginting, 2009)

Enzim amilase merupakan enzim yang dapat memecah karbohidrat atau pati menjadi senyawa lebih sederhana. Fermentasi merupakan salah satu kegiatan yang melibatkan enzim sebagai katalisator dan enzim-enzim yang digunakan merupakan enzim yang berasal dari mikroorganisme tertentu (Purwaningsih, 2008). Fermentasi juga dilakukan dalam kegiatan perikanan budidaya, yaitu fermentasi pada bahan baku pakan ikan. Hal tersebut memiliki tujuan untuk meningkatkan nutrisi pada pakan yang diproduksi, seperti yang dijelaskan oleh Amri (2007) dalam penelitiannya bahwa fermentasi bahan baku pakan memiliki manfaat untuk meningkatkan nilai nutrisi sehingga dapat dimanfaatkan secara efektif oleh ikan, serta meningkatkan pertambahan bobot dan menurunkan konversi pakan.

Darmawiyanti dan Baidhowi (2015) menjelaskan salah satu tahap dalam proses pembuatan pakan ikan adalah proses pengeringan dengan cara dipanaskan untuk mengurangi kadar air dalam bahan pakan tersebut. Pemanfaatan enzim yang berasal dari bakteri termofilik memilik potensi lebih efektif untuk digunakan dalam proses fermentasi bahan baku pakan karena dalam bakteri termofilik mengandung enzim termostabil, dimana enzim tersebut tetap stabil dan tidak terdenaturasi pada suhu tinggi. Enzim amilase yang berasal dari bakteri Pseudomonas stutzeri A.WB.50.1 sebagai enzim fermentasi pada bahan baku pakan ikan belum dilakukan, oleh sebab itu perlu dilakukan penelitian lebih lanjut untuk mengetahui manfaatnya secara optimal.

\section{KESIMPULAN}

Bakteri termofilik yang diperoleh dari sumber air panas Way Belerang Kalianda, Lampung Selatan adalah Pseudomonas stutzeri A.WB.50.1 yang memiliki potensi penghasil enzim amilase termostabil. Bakteri ini menghasilkan enzim amilase dengan diameter zona hambat paling besar yaitu $15,44 \mathrm{~mm}$ pada suhu inkubasi $50^{\circ} \mathrm{C}$. 


\section{DAFTAR PUSTAKA}

Amri M. 2007. Pengaruh bungkil kelapa sawit pada pakan ikan mas (Cyprinus carpio). Jurnal Ilmu Pertanian Indonesia 9(1): 71-76

Asnawi AH. 2006. Keanekaragaman bakteri termofilik yang terdapat dalam sumber air panas di Taman Wisata Pasudan Pacet, Kabupaten Mojokerto Jawa Timur. (Skripsi). Universitas Negeri Malang

Darmawiyanti V, Baidhowi. 2015. Teknik produksi pakan buatan di Balai Perikanan Budidaya Air Payau (BPBAP) Situbondo Jawa Timur. Jurnal Ilmu Perikanan 6(2): 118-124

Endah P, Maria Y, Putra, Surya R. 2012. Isolasi dan identifikasi bakteri termofilik dari sumber mata air panas singgahan di Songgoriti setelah dua hari inkubasi. Jurnal Teknik Pomits 1(1): 1-5

Ginting J. 2009. Isolasi bakteri dan uji aktivitas enzim amilase kasar termofilik dari sumber air panas Semangat Gunung Kabupaten Kao, Sumatera Utara. (Tesis). Universitas Sumatera Utara

Hardhianto, Mochammad D, Rahardja S, Gunanti M. 2010. Efektivitas bakteri Pseudomonas sebagai pengurai bahan organik (protein karbohidrat, lemak) pada air limbah pembenihan ikan lele dumbo (Clarias sp.) sistem sirkulasi tertutup. (Tesis). Universitas Airlangga

Herlina M. 2010. Isolasi bakteri indigen sebagai pendegradasi bahan organik pada pembeniha ikan lele dumbo sistem resirkulasi tertutup. (Skripsi). Fakultas Perikanan dan Ilmu Kelautan. Universitas Airlangga

Karina B. 2010. Isolasi bakteri termofilik dari sumber air panas di Songgoriti. (Prosiding). Institut Teknologi Sepuluh Nopember
Ostell JM, Wheelan SJ, Kans JA. 2001. The NCBI data model. In: A. D. Baxevanis \& B. F. F. Ouellette (Eds.). Bioinformatics: A Practical Guide to the Analysis of Genes and Proteins. Second Edition. John Wiley \& Sons, Inc. 19-43 pp

Poedjiadi A, Supriyanti FMT. 2009. Dasar-Dasar Biokimia. Universitas Indonesia. Jakarta

Prescott LM, Harley JP, Klein DA. 2008. Microbiology. William C. Brown Publishers. USA

Purwaningsih E. 2008. Pengaruh komposisi bahan baku dan bahan pembungkus terhadap mutu tempe kacang. Jurnal UM. 31(1)

Rafiah M. 2016. Identifikasi isolat bakteri termofilik dari sumber air panas Lejja, Kabupaten Soppeng. Jurnal Al-Kimia. Jurusan Kimia Fakultas Sains dan Teknologi. UIN Alauddin Makasar

Sianturi DC. 2008. Isolasi bakteri dan uji aktivitas amilase termofil kasar dari sumber air panas Penen Sibirubiru Sumatera Utara. (Tesis). Universitas Sumatera Utara

Sutimiharja N. 2008. Isolasi bakteri dan uji aktivitas amilase termofil kasar dari sumber air panas Gurukinayan Karo Sumatera Utara. (Tesis). Universitas Sumatera Utara

Suyono Y. 2010. Penentuan spesies bakteri Pseudomonas dan analisis phylogenetic tree secara bioinformatika. Jurnal Biopropal Industri 1(2): $24-30$

Syafriyani D. 2013. Karakteristik isolat MV2.7 termoamilolitik dari sumber air panas Sungai Medang Kerinci Jambi. (Prosiding Semirata FMIPA). Universitas Lampung 